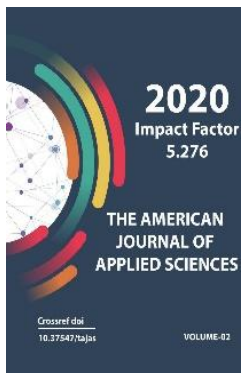

Journal Website: http://usajournalshub.c om/index,php/tajas

Copyright: Original content from this work may be used under the terms of the creative commons attributes 4.0 licence.

\section{Dust-Holding Properties Of Wood And Shrub Species In The} Conditions Of The Republic Of Karakalpakstan

\author{
A.Qayumov \\ Professor ,Doctor Of Agricultural Sciences, Tashkent State Agrarian University, Uzbekistan
}

\author{
J.S.Boltaniyozov \\ Assistant Teacher , Nukus Branch, Tashkent State Agrarian University, Uzbekistan
}

\title{
ABSTRACT
}

The article presents the results of a study on the dust retention properties of tree and shrub species used in landscaping in the city of Nukus, Republic of Karakalpakstan. According to the results, the trees and shrubs used in the landscaping of Nukus had the following indicators in terms of dust retention: the highest results were observed in mulberry $(280 \mathrm{~g} / \mathrm{m} 2)$ and Cirrus elm $(270 \mathrm{~g} / \mathrm{mz})$. The lowest rates were observed in the ailanthus, acacia and maple. Hence, it was found that trees with rugged leaves retain more dust than deciduous trees.

\section{KEYWORDS}

Landscaping, tree, shrub, dust, dust retention rate, leaf morphology, patsy-leaved slate.

\section{INTRODUCTION}

The extent of use of tree species in urban environments and settlements is primarily determined by their stability, durability, productivity and efficiency. Therefore, the development of a scientifically based procedure for the selection of tree species and their placement will not only effectively address the problems of ecological and 
architectural planning of settlements, but also significantly reduce material costs in the field of green construction. In this regard, the most important task of the study of native trees is their introduction for green building purposes, the formation of an assortment of ornamental plants $[1,3]$.

The range of plants is determined regionally, that is, the set of its species is determined by specific climatic, socioeconomic and historical conditions.

However, regardless of regional characteristics, the range must meet a number of general requirements. These issues are reflected in the research of scientists in Central Asia, including the Republic of Uzbekistan [2].

\section{METHODS AND MATERIALS}

A comprehensive study of the phenology of local and induced trees during the growing season in Nukus, Republic of Karakalpakstan, as well as their degree of dust retention, resistance of trees to this climate and soil conditions, wood structure and seed quality was carried out on a 6-point scale. In order to study the seasonal phenomena, the development of trees and shrubs in different seasons was observed. Knowing the laws of seasonal events allows you to plant propagate and use trees and shrubs in the right climatic conditions. Based on the data obtained from the observation of seasonal events, it is possible to create a phenospectrum and phenocartography of species and varieties [4]. RESEARCH RESULTS

Our research is aimed at determining the dust retention properties of trees and shrubs growing in the conditions of the Republic of Karakalpakstan.

In an urban setting, plants are affected by a number of environmental factors: climate, edaphic, industrial, and so on. In a large part of the urban area, green crops are exposed to high anthropogenic pressures chemical, physical, biological and complex pollution. As a result, the special conditions for the survival of phytocenoses, their ability to survive, and the full performance of their functions, environmental protection, sanitation and other useful features are limited.

Under the constant increase of manmade pressure on the urban population, green crops are becoming a powerful tool to reduce the negative factors of life.

The city's green spaces are part of a comprehensive green zone - a unique system of interconnected elements of the city and its surrounding landscape designed to address environmental issues and improve working conditions, living and recreation.

Green fields clean the city air from dust and gases. Along the roads, green crops absorb the polluted air flow and trap 60-70 percent of the dust. Most of the dust settles on leaves, conifers, twigs, and tree trunks. During the rain, this dust washes off the ground. Beneath the green fields, downward air currents occur due to the temperature difference. Not only trees and shrubs, but also lawns prevent the spread or movement of dust, which slows down the movement of dust caused by wind from different places. The amount of dust in the air between green crops is 2-3 times less than in open cities. Tree plantations reduce airborne dust, even when there are no leaves. In cities, the amount of dust between the trees is 2.5 times less than at a distance of $250 \mathrm{~m}$ from its edge. The dust retention properties of different trees and shrubs are not the same and depend on the morphological characteristics of the leaves. The face is rough and the uneven leaves are the most dust-trapping. If we assume that the amount of dust collected in $1 \mathrm{~cm} 2$ of a poplar leaf is equal to 1 , then the amount of dust in a 
sharp-leaved maple leaf of the same size is 2, in a nasturtium 3 , in a slate 6 . The dust that settles on the leaves is periodically washed away by rain and shed by the wind, and the leaves are again able to hold the dust [3].

Tree branches reduce air dust by $42.2 \%$ during the growing season and by $37.5 \%$ in the absence of leaf cover. Even relatively small city gardens reduce city air pollution by $30-40$ percent in summer.

Our studies have found that the dust retention properties of different tree and shrub species are not the same. In particular, corrugated or sticky leaves retain significantly more dust than smooth leaves (Table 1).

Table 1

Dust retention rates of trees and shrubs in Nukus

\begin{tabular}{|c|c|c|c|c|}
\hline \multirow{2}{*}{ № } & \multirow{2}{*}{ Plant } & \multirow{2}{*}{$\begin{array}{c}\text { Total leaf area, } \\
\mathrm{m}^{2}\end{array}$} & \multicolumn{2}{|c|}{ The amount of dust } \\
\hline & & & total, $\mathrm{kg}$ & $\mathrm{g} / \mathrm{m}^{2}$ \\
\hline \multicolumn{5}{|c|}{ Trees } \\
\hline 1. & $\begin{array}{l}\text { Ailanthus altissima (Mill)- } \\
\text { Swingle }\end{array}$ & 25 & 2,9 & 116,0 \\
\hline 2. & Robinia pseudoacacia $L$ & 12 & 0,57 & 47,5 \\
\hline 3. & Ulmus parvifolia & 16 & 4,2 & 262,5 \\
\hline 4. & Gleditsia triacanthosL. & 7 & 0,9 & 128,6 \\
\hline 5. & Acer campestre L. & 17 & 1,9 & 111,8 \\
\hline 6. & Salix & 15 & 3,5 & 233,3 \\
\hline 7. & Acer negundo $L$. & 22 & 3,2 & 145,5 \\
\hline 8. & Morus & 11 & 2,9 & 263,6 \\
\hline
\end{tabular}


The American Journal of Applied Sciences

\begin{tabular}{|c|l|c|c|c|}
\hline 9. & Populus Canadensis & 18 & 2,1 & 116,7 \\
\hline 10. & Fraxinus excelsior L. & 12 & 2,6 & 216,7 \\
\hline \multicolumn{3}{|c|}{ Shrubes } \\
\hline 1. & Caragana arborescens Lam. & 1 & 0,07 & 70 \\
\hline 2. & Evionumus & 1 & 0,05 & 50 \\
\hline 3. & Red elder & 1 & 0,05 & 50 \\
\hline 4. & Elaeagnus angustifolia L. & 1 & 0,09 & 90 \\
\hline 5. & Syringo & 1 & 0,14 & 140 \\
\hline 6. & Spiraea hypericifolia & 1 & 0,07 & 70 \\
\hline 7. & Ligustrum & 1 & 0,04 & 40 \\
\hline
\end{tabular}

According to Table 1, the trees and shrubs used in the landscaping of Nukus had the following indicators of dust retention: the highest results were observed in mulberry (280 g/ m2) and deciduous elm (270 g / m2). The lowest rates were observed in altitude acacia, white acacia and field maple trees. Hence, it was found that trees with rough leaves retain more dust than deciduous trees.

\section{CONCLUSIONS, SUGGESTIONS AND RECOMMENDATIONS}

In summary, the morphological structure of tree leaves determines the degree of dust retention in urban conditions. In the landscaping of the city of Nukus, it is recommended to build protective trees consisting of Ulmus parvifolia, Salix and Acer negundo $L$ perpendicular to the main wind direction.

\section{REFERENCES}

1. Бердиев Э.Т., Холмуротов М.З., Содиқов И.С., Ўроқов А.Х., Касимходжаев Б.К., Гуломходжаева Ш.Ф. Ўзбекистонда автомобиль йўлларини кўкаламзорлаштириш учун манзарали дарахт-буталар ассортименти // Ўзбекистон аграр фани хабарномаси Вестник аграрной науки Узбекистана. Тошкент, 2019. - № 3 (77). - 134-138 6 ( Berdiev E.T., Xolmurotov M.Z., Sodiqov I.S., Uroqov A.X., Kasimhodjaev B.K., Gulomhodjaeva SH.F. Assortment of ornamental trees and shrubs for landscaping of roads in Uzbekistan // 
Bulletin of agrarian science of Uzbekistan.

- Tashkent, 2019. - № 3 (77). - 134-138 p.)

2. . Жумадилова А. Ж. Пылеудерживающая способность древесных и кустарниковых растений //Новости науки Казахстана. 2014. - №. 2 (120). - С. 38.

3. Кайимов А.К. Биогеоценозы лесоаграрного ландшафта орошаемых земель. - Т.:Фан, 1993. - 123 с.

4. . Кайимов А., Бердиев Э.Т. Дендрология. - Тошкент: Фан ва технология, 2009. - 56. ( Kayimov A., Berdiev E.T. Dendrology. Tashkent: Fan va Texnologiya, 2009. - 5 p. 